\title{
Comparison between Insulin-like Growth Factor Binding Protein-1 Level and Bishop Score as Predictor of Successful Labor Induction in Full Term Pregnancy with Preeclampsia
}

\author{
Nurul Setiyorini ${ }^{1}$, Ratnasari Dwi Cahyanti ${ }^{2}$ \\ ${ }^{1}$ Resident of Obstetrics and Gynecology Department, Medical Faculty, Diponegoro University, Semarang, Indonesia \\ ${ }^{2}$ Staff of Obstetrics and Gynecology Department, Medical Faculty, Diponegoro University, Semarang, Indonesia \\ *corresponding author, email: dr.noeroelanindita@gmail.com
}

\begin{abstract}
Introduction: preeclampsialeclampsia contributed to $30 \%$ of maternal mortality in RSUP Dr. Kariadi. Pre-induction bishop score assessment is a standard for cervical maturity estimation. Other predictors currently being developed, including insulin-like growth factor binding protein-1 (IGFBP-1). However, there is no cut-off point for IGFBP-1 examination in full term pregnancy, especially with preeclampsia and its complications. Objective: to find IGFBP-1 levels and Bishop Score differences in preeclampsia women with induction labor.

Methods: this prospective observational cohort study was conducted in preeclampsia women with gestational age $\geq 37$ weeks planned labor induction at Obstetrics and Gynecology Ward RSUP Dr. Kariadi Semarang and networking hospital during study period ( $n=66)$. History taking, physical examination, proteinuria, cervical mucus IGFBP-1, and bishop score calculation was performed. Statistical analysis was performed with paired-t test, followed by ROC for cut-off value of successful induction prediction, and logistic regression to determine confounding variables effect on IGFBP-1 levels.

Results: The average Bishop score of 66 subjects was $2.5 \pm 1.81$ and $2.6 \pm 1.8$ for women who deliver $\leq 24$ labor and in labor for $\leq 12$ hours, respectively. Although the bishop score was higher in the successful labor group, there was no significant difference between groups. Mean IGFBP-1 value was $8.29 \pm 5.033$ $\mathrm{mcg} / \mathrm{L}$ with median value of $10.8 \mathrm{mcg} / \mathrm{L}$. Successful induction had significant higher IGFBP-1 levels with area-under-curve (AUC) 0.76 and 8.145 cutoff value ( $p=0.002, R R=5.1)$
\end{abstract}

Conclusion: IGFBP-1 level with cutoff point 8.145 can be used as predictor of successful labor induction in term pregnancy with preeclampsia.

Keywords: preeclampsia, labor induction, insulin-like growth factor binding protein-1, Bishop Score

\begin{abstract}
ABSTRAK
Pendahuluan: preeklamsia/eklampsia menyebabkan 30\% mortalitas maternal di RSUP Dr. Kariadi. Pemeriksaan skor bishop sebelum induksi persalinan merupakan standar untuk memperkirakan maturasi serviks. Saat ini, banyak prediktor lain yang sedang diteliti, temasuk insulin-like growth factor binding protein-1 (IGFBP-1), namun belum ada cut-off point pemeriksaan IGFBP-1 pada kehamilan aterm dengan preeklamsia dan komplikasi preeklamsia. Tujuan: untuk mengetahui perbedaan kadar IGFBP-1 dan skor bishop pada pasien preeclampsia yang menjalani induksi persalinan.

Metode: penelitian kohort prospektif observasional ini dilakukan pada pasien preeklamsia dengan usia kehamilan $\geq 37$ minggu yang direncanakan menjalani induksi persalinan di Bangsal Obstetri dan Ginekologi RSUP Dr. Kariadi Semarang dan RS jejaring selama periode penelitian ( $\mathrm{n}=66$ ). Anamesis, pemeriksaan fisik, proteinuria, IGFBP-1 lendir serviks, dan skor bishop dilakukan pengukuran Analisis statistik dilakukan dengan uji T-berpasangan, diikuti perhitungan ROC untuk mengetahui nilai cut off prediksi keberhasilan induksi, dan regresi logistik untuk menentukan efek variabel perancu terhadap kadar IGFBP-1.

Hasil: Dari 66 subjek, rerata skor bishop adalah 2,5 $\pm 1,81$ dan 2,6 $\pm 1,8$ pada wanita yang bersalin $\leq 24$ jam dan inpartu $\leq 12$ jam, secara berurutan. Meskipun skor bishop didapatkan lebih tinggi pada kelompok berhasil induksi, namun tidak didapatkan perbedaan bermakna

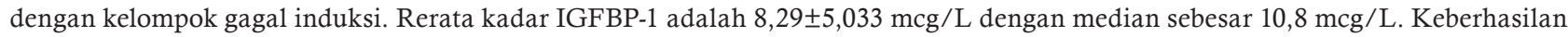
induksi diketahui memiliki kadar IGFBP-1 yang lebih tinggi dengan area dibawah kurva (AUC) sebesar 0,76 dan nilai cut off sebesar $8,145(\mathrm{p}=0,002, \mathrm{RR}=5,1)$.

Kesimpulan: IGFBP-1 dengan nilai cut-off 8.145 dapat digunakan sebagai predictor keberhasilan induksi persalinan pada kehamilan aterm wanita degan preeklamsia
\end{abstract}

Keywords: preeklampsia, induksi persalinan, insulin-like growth factor binding protein-1, skor bishop

\section{INTRODUCTION}

Nowadays, preeclampsia is still the top three cause of maternal and fetal morbidity and mortality, with 128,273 annual incidence of preeclampsia in
Indonesia or about $5.3 \%$, with no significant decrease in the last two decades (Wibowo et al., 2016). In RSUP dr. Kariadi, preeclampsia/eclampsia contributed to $30 \%$ of maternal mortality in 2016 (Anonim, 2016)

Copyright @2020 Authors. This is an open access article distributed under the terms of the Creative Commons Attribution-NonCommercialShareAlike 4.0 International License (http://creativecommons.org/licenses/by-nc-sa/4.0/), which permits unrestricted non-commercial use, distribution, and reproduction in any medium, provided the original author and source are properly cited. 
Setiyorini, et al.

therefore need more appropriate management.

Management of preeclampsia includes both active and expectative management. Active management is done by immediate delivery once pregnancy reaches aterm (Wibowo et al., 2016). In preeclampsia which not been in labor yet, induction of labor becomes an option for pregnancy termination (National Collaborating Centre for Women's and Children's Health, 2010; the American College of Obstetricians and Gynecologists, 2013). However, before induction of labor is performed, a number of examinations are performed in order to estimate successful induction. Bishop Score currently a standard to estimate cervical maturation. Several studies have shown that cervical maturity is a major predictor of successful labor induction compared to other factors assessed in the Bishop score. Bishop score is a simple and easy examination; however, it is a subjective scoring with high inter- and intra-observer variability with low predictive value to assess induction outcome (Benediktsdottir, Eggebø and Salvesen, 2015).

Considering that cervical maturity factor plays an important role in the successful induction of labor, several studies have been developed to obtain an easier and objective predictor to predict successful labor induction. One of them is Insulin-like Growth Factor Binding Protein 1 (IGFBP-1). IGFBP-1 will be found in cervical secretions, its presence in the cervical mucus will shows decidual activation and opening of the internal uterine ostium (Rahkonen, 2010; Benediktsdottir, Eggebø and Salvesen, 2015; Kosinska-Kaczynska et al., 2015). Previous study found that IGFBP-1 had a specificity value of $93 \%$ compared with $83 \%$ predictive value of Bishop Score in predicting premature labor (Conde-Agudelo et al., 2011). However, there are no cut-off points of IGFBP1 in full term pregnancy, especially with preeclampsia and its complications.

This study was aimed to analyze the comparison between IGFBP-1 levels in cervical mucus and Bishop's score to predict the success of labor induction in full term pregnancy with preeclampsia.

\section{METHODS}

\section{Design, Time and Place}

This was an observational study with prospective cohort design. The subjects were women, gestational age $\geq 37$ weeks, with preeclampsia or severe preeclampsia who attend and planned for labor induction treated in the Obstetrics and Gynecology Ward at RSUP dr. Kariadi Semarang and networking hospitals during the study period that met the criterias. The study was conducted in March-May 2017. This study has been http://jurnal.unissula.ac.id/index.php/sainsmedika

approved by institutional etchics (No. 84/EC/FKRSDK/III/2017) comittee prior sampling and data collection.

\section{Sample}

Singleton, head presentation, intrauterine preeclampsia pregnancy with gestational age $\geq 37$ weeks, without labor sign, and willing participate in the study by signing the informed consent. The minimum sample size required in this study was 64 people. Sampling was done with consecutive sampling.

\section{Data collection}

Primary data obtained from patient's history, physical examination, proteinuria, Insulin-like Growth Factor Binding Protein 1 level prior induction. Secondary data was taken from patient medical record to complete primary data.

\section{Data Analysis}

Data was analyzed using SPSS software. Comparison was done by paired T-test if data was normally distributed. ROC test was performed to determine cut off value of successful induction prediction, and logistic regression test to find the effect of confounding variables. Data was presented by frequency, percentage, picture and table.

\section{RESULTS}

\section{Subject Characteristic}

Average maternal age was $29.8 \pm 6.05$ years, with $43.9 \%$ of the subject belong to $20-30$ years age categories. Majority of participants are multiparity (74.2\%) with overweight BMI categories (54.5\%). Highest blood pressure category comprises $60.6 \%$ of $\mathrm{PE}$ group. The fetal weight estimation categories were $<3500$ gram or $80.3 \%$ with birth weight $<3500$ gram in $75.8 \%$.

\section{Labor Induction}

The succession rate of labor induction was shown in Table 1.

In table 1 we found that the majority of subjects were delivered $<24$ hours $(77.3 \%)$ and 15 $(22.7 \%)$ subjects failed to perform vaginal delivery and underwent per abdominal delivery instead. Fortynine subjects managed to achieve labor within 12 hours. Two subjects achieve labor in $>12$ hours but underwent successful vaginal delivery within 24 hours.

\section{Bishop's Score}

The mean Bishop's score of all study subjects was $2.4 \pm 1.71$, the median was 2 , the minimum score 
http://jurnal.unissula.ac.id/index.php/sainsmedika

Comparison between Insulin-like Growth Factor Binding Protein-1 Level and Bishop Score as Predictor of Successful ...

Table 1 .The Succession of Labor Induction $(n=66)$

\begin{tabular}{lc}
\hline The Success of Labor Induction & $\mathbf{n ~ ( \% )}$ \\
\hline Delivery in $\leq 24$ hours & \\
$-\quad$ Yes & $51(77.3)$ \\
No & $15(22.7)$ \\
$-\quad$ Labor in $\leq 12$ hours & \\
$-\quad$ No & $49(74.2)$ \\
\hline
\end{tabular}

Table 2. The Bishop's Score Based on the Successful labor and stage 1 parturition Induction

\begin{tabular}{|c|c|c|}
\hline & $\begin{array}{c}\text { Bishop Score } \\
\text { Mean } \pm S D ; \text { Median (min-max) }\end{array}$ & $\mathbf{p}^{¥}$ \\
\hline $\begin{array}{l}\text { Delivery in } \leq 24 \text { hours } \\
\text { - } \quad \text { Yes } \\
\text { - } \quad \text { No }\end{array}$ & $\begin{array}{l}2.5 \pm 1.81 ; 2(0-6) \\
2.1 \pm 1.30 ; 2(1-5)\end{array}$ & $\begin{array}{c}0.5 \\
-\end{array}$ \\
\hline $\begin{array}{l}\text { Labor in } \leq 12 \text { hours } \\
-\quad \text { Yes } \\
-\quad \text { No }\end{array}$ & $\begin{array}{l}2.6 \pm 1.80 ; 2(0-6) \\
2.1 \pm 1.41 ; 2(0-5)\end{array}$ & $\begin{array}{c}0.4 \\
- \\
\end{array}$ \\
\hline
\end{tabular}

$\mathrm{SD}=$ Standard deviations; Min=Minimum; $\mathrm{Max}=$ Maximum

Table 3. IGFB-1 Level and Success of Labor Induction

\begin{tabular}{lcc}
\hline Induction Success Criteria & IGFBP Level & $\mathbf{p}^{¥}$ \\
\cline { 2 - 3 } Delivery in $\leq 24$ hours & Mean \pm SB; Median (min-max) & \\
- Yes & $9.34 \pm 4.729 ; 11.13(0.01-25.93)$ & 0,002 \\
$-\quad$ No & $4.73 \pm 4.494 ; 3.60(0.02-11.26)$ & \\
Labor in $\leq 12$ hours & & \\
- Yes & $9.26 \pm 4.811 ; 11,11(0.01-25.93)$ & 0,01 \\
- No & $5.49 \pm 4.722 ; 4.81(0.02-11.26)$ & - \\
\hline
\end{tabular}

$\mathrm{SD}=$ Standard Deviation; Min=Minimum; $\mathrm{Max}=$ Maximum

Table 4. Area Under Curve and cut-off value of Bishop score and IGFBP-1 level in labor $\leq 12$ hours

\begin{tabular}{lccc}
\hline Predictor & Area Under ROC Curve (CI 95\%) & p & cut-off value \\
\hline Bishop score & $0.56(0.41 \mathrm{~s} / \mathrm{d} \mathrm{0.710)}$ & 0.4 & 1.5 \\
IGFBP level & $0.70(0.56 \mathrm{~s} / \mathrm{d} 0.85)$ & 0.01 & 8.145 \\
\hline
\end{tabular}

Table 5. IGFBP-1 Level and occurrence of labor in $\leq 12$ hours

\begin{tabular}{ccccc}
\hline \multirow{2}{*}{ IGFBP Level $(\boldsymbol{\mu g} / \mathbf{L})$} & \multicolumn{2}{c}{ Labor in $\leq \mathbf{1 2}$ hours } & \multirow{2}{*}{$\mathbf{p}^{*}$} & \multirow{2}{*}{ Relative Risk (RR) } \\
\cline { 2 - 3 } & No & Yes & & $3.4(1.5$ to 8.1$)$ \\
\hline 8.145 & $11(47.83 \%)$ & $12(52.17 \%)$ & 0.003 & \\
\hline 8.145 & $6(13.95 \%)$ & $37(86.05 \%)$ & & \\
\hline
\end{tabular}

$\chi^{2}$ test

was 0 and the maximum was 6 . Table 2 shows that the Bishop score of groups who deliver $\leq 24$ hours was higher than women who deliver $>24$ hours, however the difference was not significant, $p=0.5$. Subject who reach labor in $\leq 12$ hours have higher Bishop's score than subject who reach labor in $>12$ hours, the difference was not significant $(p=0.4)$. Comparison of Bishop score based on successful induction of labor is also shown in figure 1.

\section{IGFBP-1 Serum Level}

The mean IGFBP-1 serum level of all subjects was $8.29 \pm 5.033 \mu \mathrm{g} / \mathrm{L}$, with median $10.80 \mu \mathrm{g} / \mathrm{L}$, minimum value $0.01 \mu \mathrm{g} / \mathrm{L}$ and maximum value 25.93 $\mu \mathrm{g} / \mathrm{L}$. IGFBP-1 serum levels based on successful labor induction are shown in Table 3. 
Setiyorini, et al.
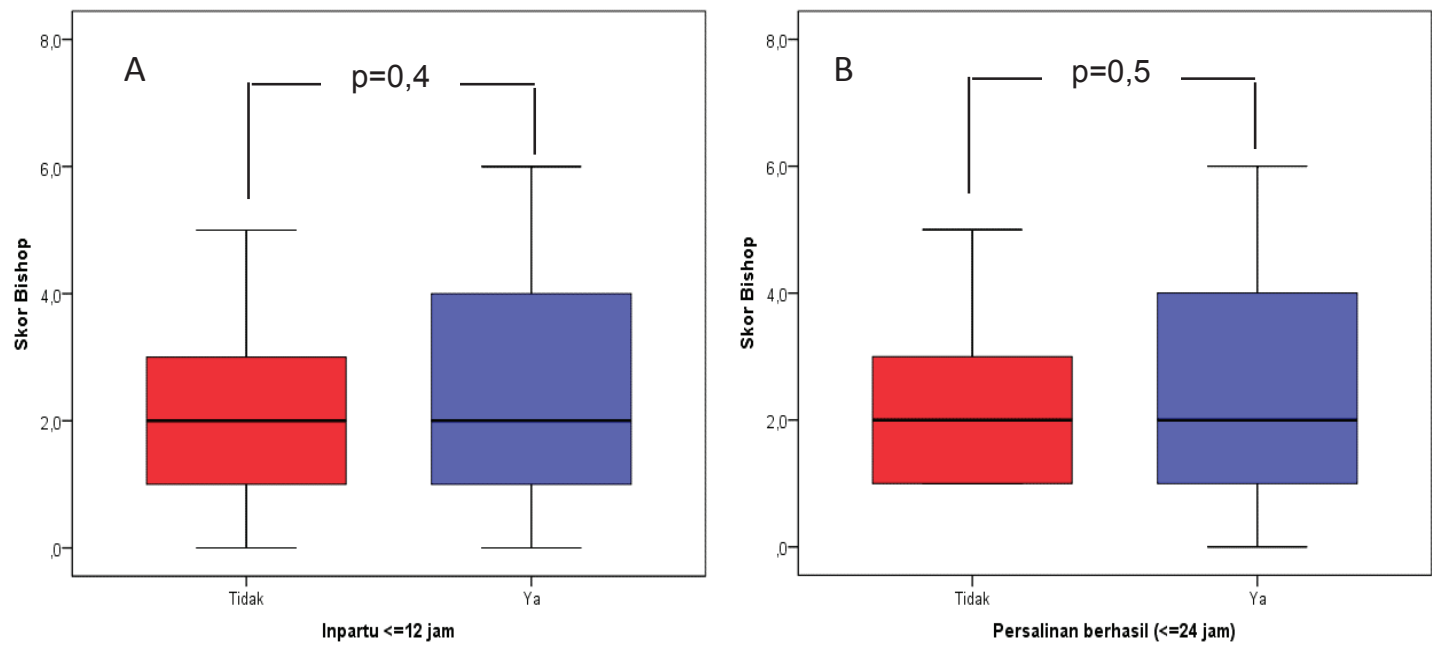

Figure 1. Bishop score of study subjects based on successful labor induction $(n=66)$. Panel A: Bishop score based on labor $\leq 12$ hours. Panel B: Bishop score based on delivery $\leq 24$ hours
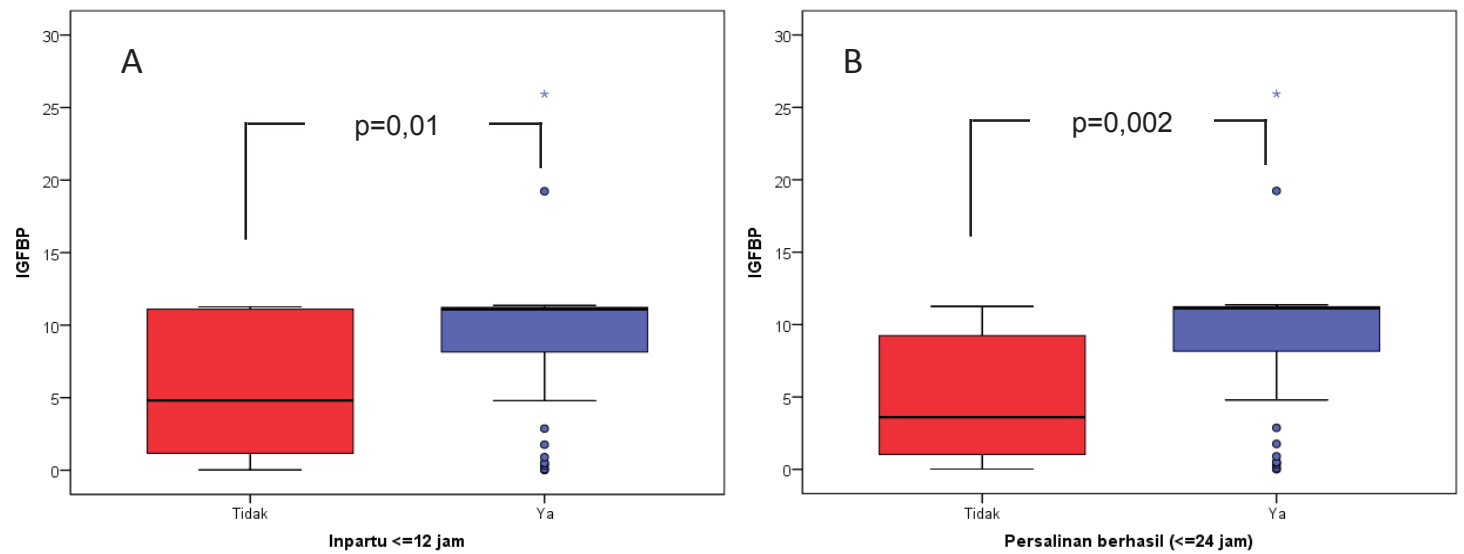

Figure 2. Serum IGFBP level $(\mu \mathrm{g} / \mathrm{L})$ of study subjects based on success of labor induction $(\mathrm{n}=66)$. Panel A: Serum IGFBP-1 level based on labor $\leq 12$ hours. Panel B: Serum IGFBP-1 level based on delivery $\leq 24$ jam

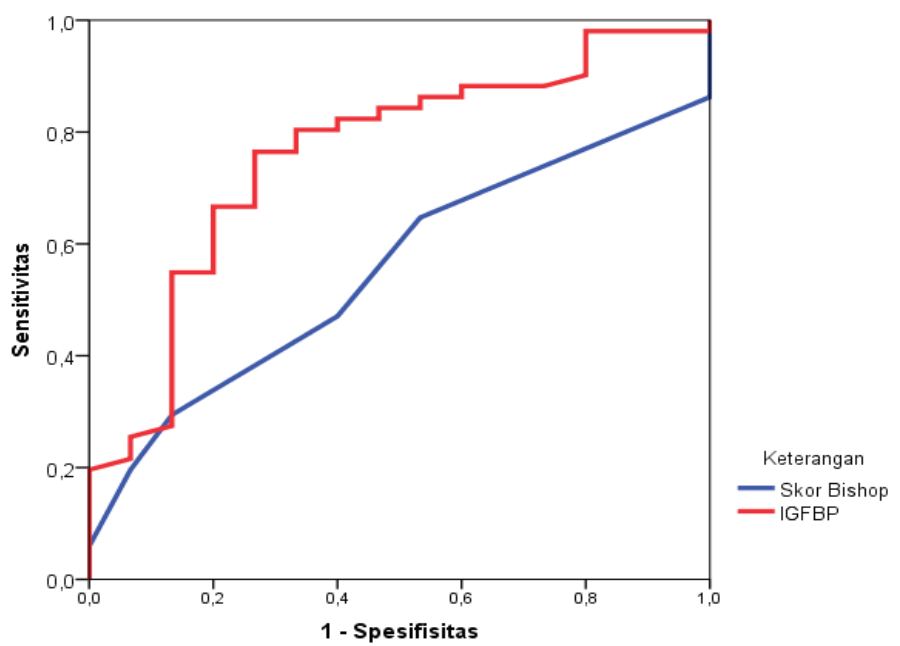

Figure 3. ROC Curve of the Bishop score and serum IGFBP-1 level to predict labor $\leq 12$ hours (n=66) 
http://jurnal.unissula.ac.id/index.php/sainsmedika

Comparison between Insulin-like Growth Factor Binding Protein-1 Level and Bishop Score as Predictor of Successful ...

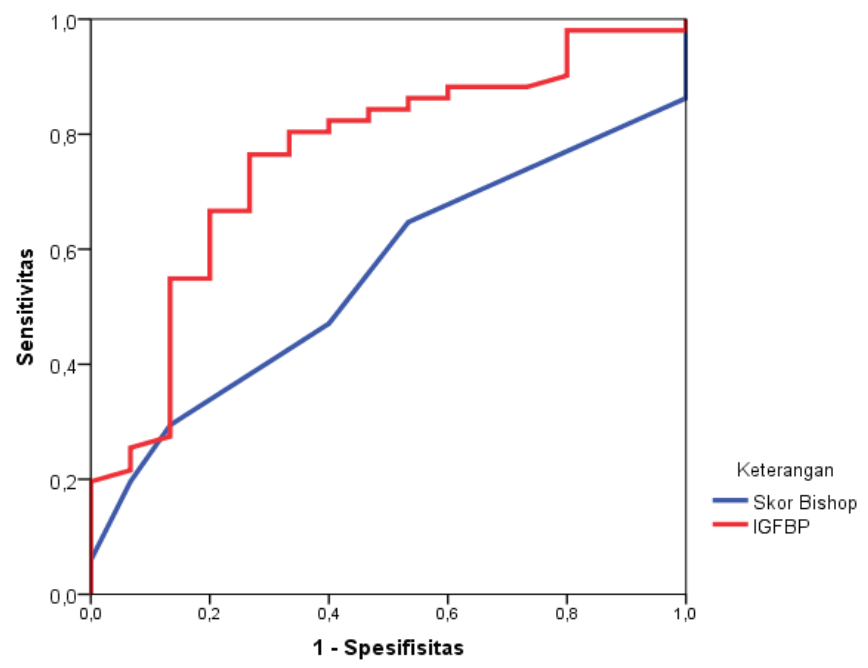

Figure 4. ROC curve of the Bishop score and serum IGFBP-1 level to predicted delivery in $\leq 24$ hours

Table 3 shows that serum IGFBP-1 level in women who deliver $\leq 24$ hours was significantly higher than women who deliver $>24$ hours $(p=0.002)$. Moreover, women who reach labor in $\leq 12$ hours have significantly higher IGFBP-1 value than women who reach labor in $>12$ hours $(p=0.01)$. Comparison of serum IGFBP levels based on successful induction of labor is also shown in Figure 2.

Bishop Score and Level of Serum IGFBP-1 as Predictor Success of Labor Induction

\section{Labor in $\leq \mathbf{1 2}$ hours}

The receiver operating characteristic (ROC) curves of the Bishop's score and serum IGFBP- 1 levels to assess labor $\leq 12$ hours were shown in figure 3 .

The area under ROC curve and the cut-off value of the Bishop score and serum IGFBP levels to predict labor $\leq 12$ hours are shown in table 4 .

The area under ROC curve of the Bishop score to predict the occurrence of labor in $<12$ hours was $0.56(p=0.4)$ and cut-off value of 1.5. The area under ROC curve of IGFBP level was $0.70(p=0.01)$ with cut-off value of 8.145 . Based on this result, IGFBP-1 level can be used to predict labor $<12$ hours.

Based on table 5 , majority of women with IGFBP1 serum level $>8.145 \mu \mathrm{g} / \mathrm{L}(86.05 \%)$, performed labor in $<12$ hours $(\mathrm{p}=0.003)$. The $\mathrm{RR}$ value was 3.4 , meaning that subjects with serum IGFBP-1 level $<8.145 \mu \mathrm{g} / \mathrm{L}$ had 3.4 fold risk of labor in $>12$ hours. Based on these result, it can be concluded that serum IGFBP levels can be used to predicted labor in $<12$ hours.

\section{Delivery in $\leq 24$ hours}

The receiver operating characteristic (ROC) curves of the Bishop score and serum IGFBP levels to assessed delivery in $\leq 24$ hours are shown in Figure
4.

Based on figures 4 and table 6 , the area under the ROC curve of the Bishop's score able to predict delivery in $<24 \mathrm{~h}$ was $0.55(\mathrm{p}=0.5)$, with a cut-off value of 1.5. The area under the ROC curve of IGFBP level was $0.76(p=0.0021)$, with a cut-off value of 8.145. Based on these result, we can concluded that serum IGFBP-1 level can be used as a predictor of delivery in $<24$ hours.

The distribution of serum IGFBP-1 based on the occurrence delivery in $<24$ hours is shown in Table 7.

Based on table 7, majority of subject with serum IGFBP-1 level $>8.145 \mu \mathrm{g} / \mathrm{L}(90.70 \%)$ had delivery in $<24$ hours $(\mathrm{p}<0.001)$. The RR score was 5.1 , meaning that subjects with serum IGFBP-1 level $<8.145 \mu \mathrm{g} / \mathrm{L}$ had 5.1 fold risk of delivery $>24$ hours. Based on these results, we can concluded that serum IGFBP-1 level can be used as a predictor of delivery in $<24$ hours.

\section{Confounding Factors that Affect Delivery within 24 Hours}

Table 8 shows that maternal age ( $p=0.5)$, BMI (0.9), blood pressure $(p=0.2)$, parity (0.3), Estimated Fetal Weight or EFW ( $p=0.7)$, Birth Weight or BW $(p=1.0)$ were not significantly associated with the delivery $<24$ hours. Because there was no significant confounding variable, the data analysis was not followed by multivariate test.

\section{DISCUSSIONS}

Majority of the subject was on reproductive age range between $20-34$ years (48 subjects) with mean age $29.8 \pm 6.05$ years. Induction was successful in 37 subjects (45.1\% in 20-30 age group and $27.5 \%$ in $30-34$ age group). This finding was similar to a study about the effectiveness of misoprostol as a labor induction agent 
Setiyorini, et al.

Table 6. The area under the ROC curve and the cut-off score of the Bishop score and serum IGFBP levels to predict delivery in $<24$ hours

\begin{tabular}{lccc}
\hline Predictor & Area Under ROC Curve (CI 95\%) & $\mathbf{p}$ & Cut-off value \\
\hline Bishop Score & $0.55(0.41 \mathrm{~s} / \mathrm{d} 0.70)$ & 0.5 & 1.5 \\
IGFBP-1 level & $0.76(0.62 \mathrm{~s} / \mathrm{d} 0.90)$ & 0.002 & 8.145 \\
\hline
\end{tabular}

Table 7. IGFBP-1 Level and occurrence of delivery in $\leq 12$ hours

\begin{tabular}{lrrrr}
\hline \multirow{2}{*}{ IGFBP Level $(\boldsymbol{\mu g} / \mathrm{L})$} & \multicolumn{2}{c}{ Delivery in $\leq \mathbf{1 2}$ hours } & \multirow{2}{*}{$\mathbf{p}^{*}$} & Relative Risk (RR) \\
\cline { 2 - 3 } & \multicolumn{1}{c}{$\mathbf{N o}$} & \multicolumn{1}{c}{ Yes } & & $5.1(1.8$ to 14.3$)$ \\
\hline$-<8,145$ & $11(47.83 \%)$ & $12(52.17 \%)$ & $<0.001$ & \\
$-\geq 8,145$ & $4(9.30 \%)$ & $39(90.70 \%)$ & & \\
\hline
\end{tabular}

${ }^{*} \chi^{2}$ test

Table 8. Confounding factors associated with successful labor

\begin{tabular}{|c|c|c|c|c|}
\hline \multirow{2}{*}{\multicolumn{2}{|c|}{ Confounding factors }} & \multicolumn{2}{|c|}{ Delivery $\leq 24$ hours } & \multirow[b]{2}{*}{$\mathbf{p}$} \\
\hline & & $\begin{array}{c}\text { No } \\
\text { n (\%) }\end{array}$ & $\begin{array}{c}\text { Yes } \\
\text { n (\%) }\end{array}$ & \\
\hline \multicolumn{5}{|c|}{ Maternal Age Category } \\
\hline & $-<20$ & $0(0.0)$ & $5(9.8)$ & $0.5^{*}$ \\
\hline & $-20-30$ & $6(40.0)$ & $23(45.1)$ & \\
\hline & $-30-34$ & $5(33.3)$ & $14(27.5)$ & \\
\hline & $-\quad \geq 35$ & $4(26.7)$ & $9(17.6)$ & \\
\hline \multicolumn{5}{|c|}{ BMI Category } \\
\hline & $-\quad<25$ & $3(20.0)$ & $13(25.5)$ & $0.9^{*}$ \\
\hline & $-25-29,9$ & $9(60.0)$ & $27(52.9)$ & \\
\hline & $-\quad \geq 30$ & $3(20.0)$ & $11(21.6)$ & \\
\hline \multicolumn{5}{|c|}{ Blood Pressure Category } \\
\hline & $-\quad P E$ & $7(46.7)$ & $33(64.7)$ & $0.2^{*}$ \\
\hline & - Severe PE & $8(53.3)$ & $18(35.3)$ & \\
\hline \multicolumn{5}{|c|}{ Parity Category } \\
\hline & $-\leq 1$ & $2(13.3)$ & $15(29.4)$ & $0.3^{\S}$ \\
\hline- & $>1$ & $13(86.7)$ & $36(70.6)$ & \\
\hline \multicolumn{5}{|c|}{ EFW Category } \\
\hline- & $<3500$ & $13(86.7)$ & $40(78.4)$ & $0.7^{\S}$ \\
\hline- & $\geq 3500$ & $2(13.3)$ & $11(21.6)$ & \\
\hline \multicolumn{5}{|c|}{ BW Category } \\
\hline- & $<3500$ & $12(80.0)$ & $38(74.5)$ & $1.0^{\S}$ \\
\hline- & $\geq 3500$ & $3(20.0)$ & $13(25.5)$ & \\
\hline
\end{tabular}

${ }^{*} \chi^{2}$ Test

${ }^{\S}$ Fisher-Exact Test

in preeclampsia, which reported average induction age of 26 years, and insignificant as a predictor of successful induction (Frass, Shuaib and Al-harazi, 2011). Another study reported successful induction in $>90 \%$ of $18-35$ age group (Vogel, Souza and Gülmezoglu, 2013).

Approximately $78 \%$ of subjects had a $\mathrm{BMI}<30$ with mean BMI $27.5 \pm 3.75$. Based on BMI factor, we could not find significant correlation with induction of labor. This result was consistent with study reported a successful induction on subjects with $\mathrm{BMI}<30$ and not correlate significantly with successful of labor induction
(Lubena, 2015; Guerra et al., 2017). Different results was obtained on different study in 2009 which reported that BMI of $<30$ was a significant factor for successful labor induction (Pevzner et al., 2017).

Other studies reported several other significant factors for labor induction, such as estimated fetal weight and parity. A study stated that fetal weight $<3500$ grams was a significant factor for successful labor induction (Chung et al., 2015). Meanwhile, our study found similar finding which $78.4 \%$ of the subjects with fetal weight $<3500$ grams could achieve stage 2 
http://jurnal.unissula.ac.id/index.php/sainsmedika

Comparison between Insulin-like Growth Factor Binding Protein-1 Level and Bishop Score as Predictor of Successful ...

labor within 24 hours after induction, however, the result was insignificant. Thirty-six $(70.6 \%)$ of the 49 multiparity subjects underwent successful induction compared to 15 (29.4\%) subjects of nulliparity groups. There were no significant differences between groups. However, several other studies might found different finding, which suggested that parity was a significant factor for successful labor induction (Vogel, Souza and Gülmezoglu, 2013; Chung et al., 2015; Guerra et al., 2017).

One study reported that prolong first stage of labor (more than 12 hours) doubles cesarean section risk. In our study, we found 2 subjects with a labor duration $>12$ hours who managed to achieve vaginal delivery within 24 hours. Multiparity is still suspected to be one of the causative factors.

Several studies either randomized controlled trial/RCT or demographic studies, reported mixed finding on successful induction in preeclampsia patient. Studies in the United States reported incidence of successful induction in term preeclampsia pregnancy was $74 \%$, while another reported significant induction failure in preeclampsia group (Kim et al., 2010; Vogel, Souza and Gülmezoglu, 2013; Roland, Warshak and Defranco, 2017). Our study found that 33 subjects with preeclampsia and 18 subjects with severe preeclampsia underwent delivery within 24 hours. There was no significant difference between groups so that the classification of preeclampsia and severe preeclampsia was not a predictor of successful labor induction.

Although there was inter- and intra-observer variability, Bishop's Score still currently serve as a gold standard for successful labor prediction. Based on Bishop's score data, we found a significantly higher score in patient with successful compared to failed delivery $(2.5 \pm 1.81$ vs $2.1 \pm 1.41$, respectively) and in those who underwent labor within 12 hours compared to $>12$ hours $(2.6 \pm 1.8$ vs $2.1 \pm 1.30)$. Although the Bishop score was higher, we found no significant difference between groups. This was in contrast with previous studies which suggested that cervical maturity is a critical determinant of successful labor induction (Teixeira et al., 2012; Lubena, 2015).

The mean of IGFBP-1 level in this study was $8.29 \pm 5.033 \mathrm{mcg} / \mathrm{L}$ with median value of $10.8 \mathrm{mcg} / \mathrm{L}$. We found that levels of IGFBP-1 in successful delivery was significantly higher with a cutoff IGFBP-1 value 8.145 ( $p=0.002$, RR 5.1). This finding was consistent with preeclampsia theory, with increment of cervical mucus IGFBP-1 level near-term. IGFBP-1 was the first sign of chorionic and decidual adhesions detachment (Kosinska-Kaczynska et al., 2015). The IGFBP-1 score in this study was lower than those found in previous study which reported a cutoff value of $10 \mathrm{mcg} / \mathrm{L}$ (Weroha and Haluska, 2012; Kosinska-Kaczynska et al., 2015).

In this study, all confounding factor was not significantly correlated with successful labor induction, hence, we could use cervical mucus IGFBP-1 level to predict successful induction.

\section{CONCLUSIONS}

In this study, IGFBP-1 level with cut-off point 8,145 can be used as predictor of successful induction of labor in term preeclampsia pregnancy. IGFBP-1 can be considered as alternative modality management, especially in preeclampsia patient who was planned to undergo induction of labor. Future research is needed to account other conditions such as serotonin and premature rupture of membranes.

\section{CONFLICT OF INTEREST}

There is no conflict of interest in this publication

\section{ACKNOWLEDGMENT}

We highly appreciate and thank the Obstetrics and Gynecology Ward at RSUP dr. Kariadi Semarang's staffs during the samples collection.

\section{REFERENCES}

Anonim (2016) Laporan Tahunan Fetomaternal. Semarang: RSUP Dr. Kariadi.

Benediktsdottir, S., Eggebø, T. M. and Salvesen, K. A. (2015) 'Agreement between transperineal ultrasound measurements and digital examinations of cervical dilatation during labor', BMC Pregnancy and Childbirth, 15(1), p. 273. doi: 10.1186/s12884-015-0704-z.

Chung, S. H. et al. (2015) 'Sonographically accessed funneling of the uterine cervix as a predictor of successful labor induction', Obstetrics \& Gynecology Science, 58(3), pp. 188-195. doi: 10.5468/ogs.2015.58.3.188.

Conde-Agudelo, A. et al. (2011) 'Novel biomarkers for the prediction of the spontaneous preterm birth phenotype: A systematic review and metaanalysis', BJOG: An International Journal of Obstetrics and Gynaecology, 118(9), pp. 10421054. doi: 10.1111/j.1471-0528.2011.02923.x.

Frass, K. A., Shuaib, A. A. and Al-harazi, A. H. (2011) 
Setiyorini, et al.

'Misoprostol for induction of labor in women with severe preeclampsia at or near term', Saudi medical journal, 32(7), pp. 679-684.

Guerra, G. V. et al. (2017) 'Factors and outcomes associated with the induction of labour in Latin America', BJOG: An International Journal of Obstetrics and Gynaecology, 116(13), pp. 17621772. doi: 10.1111/j.1471-0528.2009.02348.x.

Kim, L. H. et al. (2010) 'Is preeclampsia associated with an increased risk of cesarean delivery if labor is induced?', The Journal of Maternal-Fetal and Neonatal Medicine, 23(5), pp. 383-388. doi: 1 $0.3109 / 14767050903168432$.

Kosinska-Kaczynska, K. et al. (2015) 'Phosphorylated IGFBP-1 in predicting successful vaginal delivery in post-term pregnancy', Archives of Gynecology and Obstetrics, 292(1), pp. 45-52. doi: 10.1007/ s00404-014-3577-X.

Lubena, H. K. (2015) Perbandingan panjang serviks dengan USG transvaginal dan skor bishop sebagai prediktor keberhasilan induksi persalinan. Semarang: Universitas Diponegoro.

National Collaborating Centre for Women's and Children's Health (2010) Hypertension in pregnancy: the management of hypertensive disorders during pregnancy Hypertension in pregnancy the management of hypertensive disorders, Royal College of Obstetricians and Gynaecologists. London: Royal College of Obstetricians and Gynaecologists.

Pevzner, L. et al. (2017) 'actors predicting successful labor induction with dinoprostone and misoprostol vaginal inserts', Obstetrics and Gynecology, 114(2), pp. 261-267.

Rahkonen, L. (2010) Preterm delivery and selected http://jurnal.unissula.ac.id/index.php/sainsmedika

biomarkers: phosphorylated insulin-like growth factor-binding protein-1 and matrix metalloproteinase-8 - in cervival fluid. Helsinki: University of Helsinki.

Roland, C., Warshak, C. R. and Defranco, E. A. (2017) 'Success of labor induction for pre-eclampsia at preterm and term gestational ages', Journal of Perinatology, 37(6), pp. 636-640. doi: 10.1038/ jp.2017.31

Teixeira, C. et al. (2012) 'The Bishop Score as a determinant of labour induction success: A systematic review and meta-analysis', Archives of Gynecology and Obstetrics, 286(3), pp. 739 753. doi: 10.1007/s00404-012-2341-3.

The American College of Obstetricians and Gynecologists (2013) 'Hypertension in Pregnancy: Report of the American College of Obstetricians and Gynecologists' Task Force on Hypertension in Pregnancy Executive', the American College of Obstetricians and Gynecologists, 122(5), pp. 1122-1131.

Vogel, J. P., Souza, J. P. and Gülmezoglu, A. M. (2013) 'Patterns and Outcomes of Induction of Labour in Africa and Asia: A Secondary Analysis of the WHO Global Survey on Maternal and Neonatal Health', PLoS ONE, 8(6), p. 65612. doi: 10.1371/journal.pone.0065612.

Weroha, S. J. and Haluska, P. (2012) 'The Insulin-Like Growth Factor System in Cancer', Endocrinology and Metabolism Clinics of North America, 41(2), pp. 335-350. doi: 10.1016/j.ecl.2012.04.014.

Wibowo, N. et al. (2016) Pedoman Nasional Pelayanan Kedokteran Diagnosis dan Tatalaksana PreEklampsia. Jakarta: Perkumpulan Obstetri dan Ginekologi Indonesia (POGI). 